\title{
Silurian Kenzieana Liljedahl, 1989 (Bivalvia, Spanilidae) from Bohemia, Gotland and Sardinia
}

\author{
JIŘí KŘíŽ
}

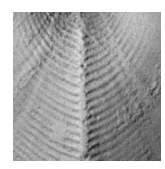

\begin{abstract}
The genus Kenzieana Liljedahl, 1989 (Nepiomorphia Kř́ž, 2007) from Perunica, the European peri-Gondwana and Baltica is the oldest known, very long ranging Silurian (late Wenlock to late Přídolí) genus of Spanilidae Kř́ž, 2007, and was most probably the ancestor of the Gorstian Algerina Kříž, 2008, and the Ludfordian Spanila Barrande, 1881. Kenzieana is represented by K. bellula (Barrande, 1881) from the Homerian (late Wenlock), and K. cardiopsis (Barrande, 1881) from the late Wenlock to the late Př́idolí. K. angusta Liljedahl, 1989, and K. lata Liljedahl, 1989 from Gotland are the junior synonyms. Distinctly inflated, foreshortened shells of Kenzieana with almost flat and circular frontal face show adaptive convergence with the Silurian Slavinka plicata (Barrande, 1881), Recent Corculum Röding, 1798, Fragum Röding, 1798, and Hippopus Lamarck, 1799. Kenzieana was very shallow and slow burrower resting in the sediment on its anterior, almost subcircular or widely elliptical and flat frontal face with a few byssal threads attached to loose detritus. - Key words: Bivalvia, Nepiomorphia, Silurian, systematics, palaeoecology, Perunica, European periGondwana, Baltica.
\end{abstract}

KŘíž, J. 2010. Silurian Kenzieana Liljedahl, 1989 (Bivalvia, Spanilidae) from Bohemia, Gotland and Sardinia. Bulletin of Geosciences 85(1), 53-60 (3 figures). Czech Geological Survey, Prague. ISSN 1214-1119. Manuscript received February 9, 2010; accepted in revised form March 2, 2010, published online March 15, 2010; issued March $22,2010$.

Jiři Kř̌̌, Czech Geological Survey, P.O. Box 85, Praha 011, Czech Republic; jiri.kriz@geology.cz.

The family Spanilidae Kříž, 2007 was created for ecologically specialized genera of Antipleurida Kříž, 2007, adapted to the life in the Silurian (Homerian-late Přídolí cephalopod limestone biofacies of peri-Gondwana regions and late Wenlock of Gotland. Kenzieana Liljedahl, 1989 represents the oldest known genus of the family. The genus is probably the ancestor of Spanila Barrande, 1881 and Tetinka Barrande, 1881, and it is related to Algerina Křiž, 2008. Dorsoventrally elongated shells and prominent radial ribs of Kenzieana are characteristic of the Spanilidae. The enantiomorphous dimorfism of Antipleurida is suppressed in the family and in different species the shells are reclining slightly or to the left or to the right. The hinge with reduced number of pseudotaxodont teeth was observed in Kenzieana and Spanila. Kenzieana was erected by Liljedahl (1989) for Kenzieana lata Liljedahl, 1989 from the Silurian of Gotland, which is junior synonym of Kenzieana cardiopsis (Barrande, 1881) (= Spanila cardiopsis Barrande, 1881) from the Silurian of the Prague Basin, Bohemia.

\section{Systematic palaeontology}

Abbreviations. $-\mathrm{V}=$ valve, $\mathrm{L}=$ length of the shell, $\mathrm{H}=$ height of the shell, $\mathrm{W}=$ width of the shell, $\mathrm{W} / 2=$ width of one valve (Kříž 1969); JK 14 931-JK 15114 (181 specimens) deposited in the collection of Jiři Kř́iž in the Czech Geological Survey, Prague; NM bivalves deposited in the National Museum, Prague. All measurements are in millimetres.

Class Bivalvia Linné, 1758

Superordo Nepiomorphia Kř́̌ž, 2007

Order Antipleurida Kř́ž, 2007

Superfamily Dualinoidea Conrath, 1887

Family Spanilidae Kříž, 2007

\section{Genus Kenzieana Liljedahl, 1989}

1881 Spanila Barrande, pp. 161-162 (partim).

1989 Kenzieana gen. nov., Liljedahl, pp. 230-232.

Type species. - Kenzieana lata Liljedahl, 1989 [= Kenzieana cardiopsis (Barrande, 1881), senior synonym], Sweden, Gotland, Silurian, early Homerian (Cyrtograptus lundgreni Biozone).

Diagnosis. - Spanilid characterized by small, obliquely obtriangular to broadly obtriangular in outline, dorso-ventrally elongated, foreshortened distinctly inflated shells. 


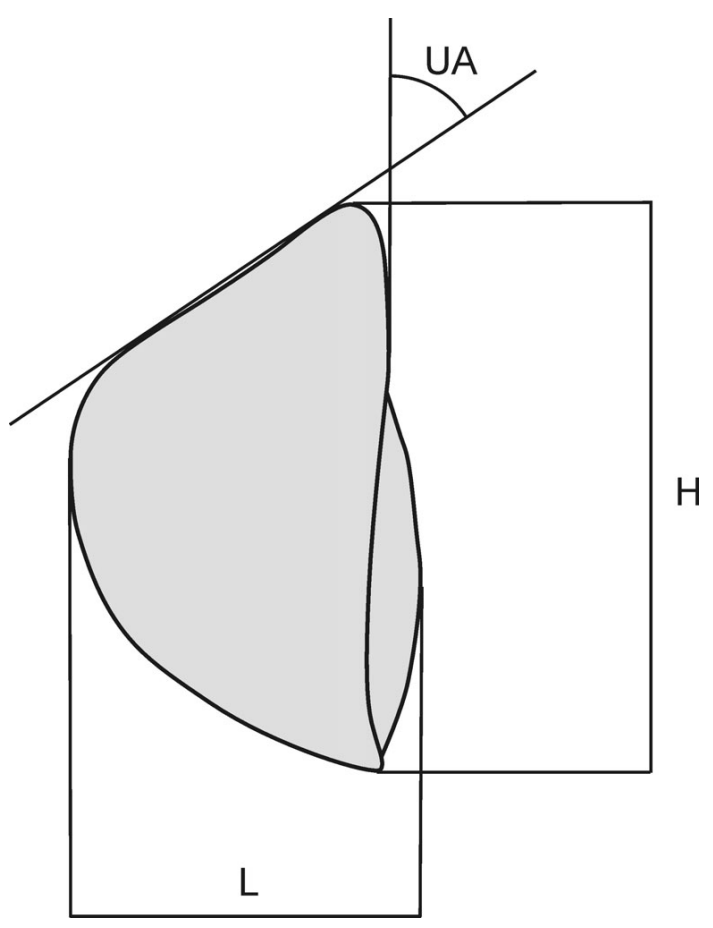

Figure 1. Schematic representation of basic morphology of the genus Kenzieana. L - length, $\mathrm{H}$ - height, UA - umbonal angle.

Outer surface with numerous radial ribs (more than 63-71) in combination with numerous growth bands of the same width. Very steep and very wide frontal face, carina between frontal face and the rest of shell, curved anteriorly. Enantiomorphous (shell is slightly inclined to the left or to the right). Hinge margin short, straight. Two blunt, spoon like and quite long, slightly dorsally curved teeth are developed on the left valve. Between two corresponding sockets on the right valve is developed one long, spoon like tooth curved dorsally and leaning against the inter-space between the teeth of the left valve. Relatively high, triangular ligamental area has radial ribs. Ligament is probably amphidetic. Posterior adductor muscle scar developed close to ventral margin, and dorsally of the posterior radial sulcus.

Remarks. - Kenzieana is very long ranging Silurian genus (late Wenlock to late Př́idolí) and was most probably the ancestor of the Ludfordian genera Spanila and Tetinka from which it differs especially by less dorsoventrally elongated shells and by numerous narrow radial ribs.

Mode of life. - Distinctly foreshortened, inflated shells with almost flat and circular frontal face representing a very specialised adaptation which shows adaptive convergence with the Silurian Slavinka plicata (Barrande, 1881) and Recent Corculum Röding, 1798, Fragum Röding, 1798, and Hippopus Lamarck, 1799 (Kř́̌̌ 1985, Liljedahl 1989). It is possible to presume that Kenzieana had very similar mode of life, being a very shallow and slow burrower (H/W 0.8-1.4) reclining in the sediment on its anterior, almost subcircular and flat frontal face with a few byssal threads attached to loose detritus. In Recent bivalves radial ribs are largely restricted to shells of borers and shallow burrowers; they have stabilizing function (Stanley 1970).

Species. - Kenzieana bellula (Barrande, 1881), late Wenlock, Bohemia and Gotland and Kenzieana cardiopsis (Barrande, 1881), late Wenlock to the late Přídolí, Bohemia, Sardinia and Gotland.

\section{Kenzieana cardiopsis (Barrande, 1881)}

Figures 2A-N, 3A, B, D, E, J, N, O

1881 Spanila cardiopsis Barr.; Barrande, pl. 212, figs II/1-12, pl. 246, figs II/5-10.

1881 Tetinka bellula Barr.; Barrande, pl. 183, figs IV/1-3, pl. 215, figs II/1-5, pl. 244, figs II/1-4.

1881 Hemicardium colonus Barr.; Barrande, pl. 183, figs IV/4-11.

1881 Goniophora phrygia Barr.; Barrande, pl. 195, figs V/8-11.

1881 Conocardium clypeus Barr.; Barrande, pl. 203, figs $\mathrm{I} / 1-2$.

1881 Hemicardium baro Barr.; Barrande, pl. 244, fig. I/1.

1881 Hemicardium noduliferum Barr.; Barrande, pl. 246, figs V/1-6.

1989 Kenzieana lata sp. n.; Liljedahl, pp. 232-234, figs $2 \mathrm{~A}-\mathrm{F}$, figs $3 \mathrm{C}, \mathrm{D}$, E, figs $4,5,8 \mathrm{D}$ and $9 \mathrm{~A}$.

Figure 2. A-N - Kenzieana cardiopsis (Barrande, 1881). A - juvenile right valve, mesoconch, JK 8851, lateral view; $\times 10$. $\bullet$ B, C, G - juvenile shell with conjoined valves, JK 8827; B - right lateral view; $\times 9.1$; C - dorso-lateral right view showing prodissoconch in umbonal part; $\times 9.6 ; \mathrm{G}-$ posterior view; $\times$ 8.4. $\bullet \mathrm{D}-$ juvenile shell with conjoined valves, JK 8840a, left dorso-lateral view showing mesoconch, $\times 7.2 . \bullet \mathrm{E}-$ juvenile right valve with mesoconch, JK 8875 , lateral view; $\times 7.2 \cdot \bullet \mathrm{F}-$ left valve, JK 8807, lateral view; $\times 5.5 \cdot \bullet \mathrm{H}-\mathrm{J}, \mathrm{M}-$ shell with conjoined valves, NM L 21416 , lectotype; $\mathrm{H}$ - dorsal view, $\times 3.8 ; \mathrm{I}-$ ventral view, $\times 3.7 ; \mathrm{J}-$ anterior view, $\times 3.3 ; \mathrm{M}$ - left lateral view, $\times 5.1 . \bullet \mathrm{K}-$ right valve, $\mathrm{JK} 8848$, lateral view; $\times 5.3 . \bullet \mathrm{L}-$ left valve, NM L 21417, paralectotype, lateral view; $\times 5 . \bullet \mathrm{N}$ - left valve, JK 8887, lateral view; $\times 5.5 . \bullet \mathrm{O}-\mathrm{S}-$ Kenzieana bellula (Barrande, 1881); O - right valve, JK 8838, lateral view; × 6.1; P - right valve, JK 8812, lateral view; × 6.6; R - left valve, JK 11236, lateral view; × 5.7; S - left valve, NM L 22424 , lectotype, lateral view; $\times$ 6.7. $-\mathrm{A}, \mathrm{D}-\mathrm{F}, \mathrm{K}, \mathrm{N}-\mathrm{Na}$ Břekvici locality near Praha-Butovice, lower Ludlow, Neodiversograptus nilssoni Biozone. - B-C, G, O, P - Arethusina Gorge locality near Praha- Keporyje, Wenlock, Testograptus testis Biozone. • H-J, L, M - Kozel locality near Beroun-Lištice, lower Ludlow. $\bullet$ R - Vyskočilka locality near Praha-Malá Chuchle, Wenlock, Testograptus testis Biozone. • S - Kační Quarry near Praha-Butovice, Wenlock, Testograptus testis Biozone. 


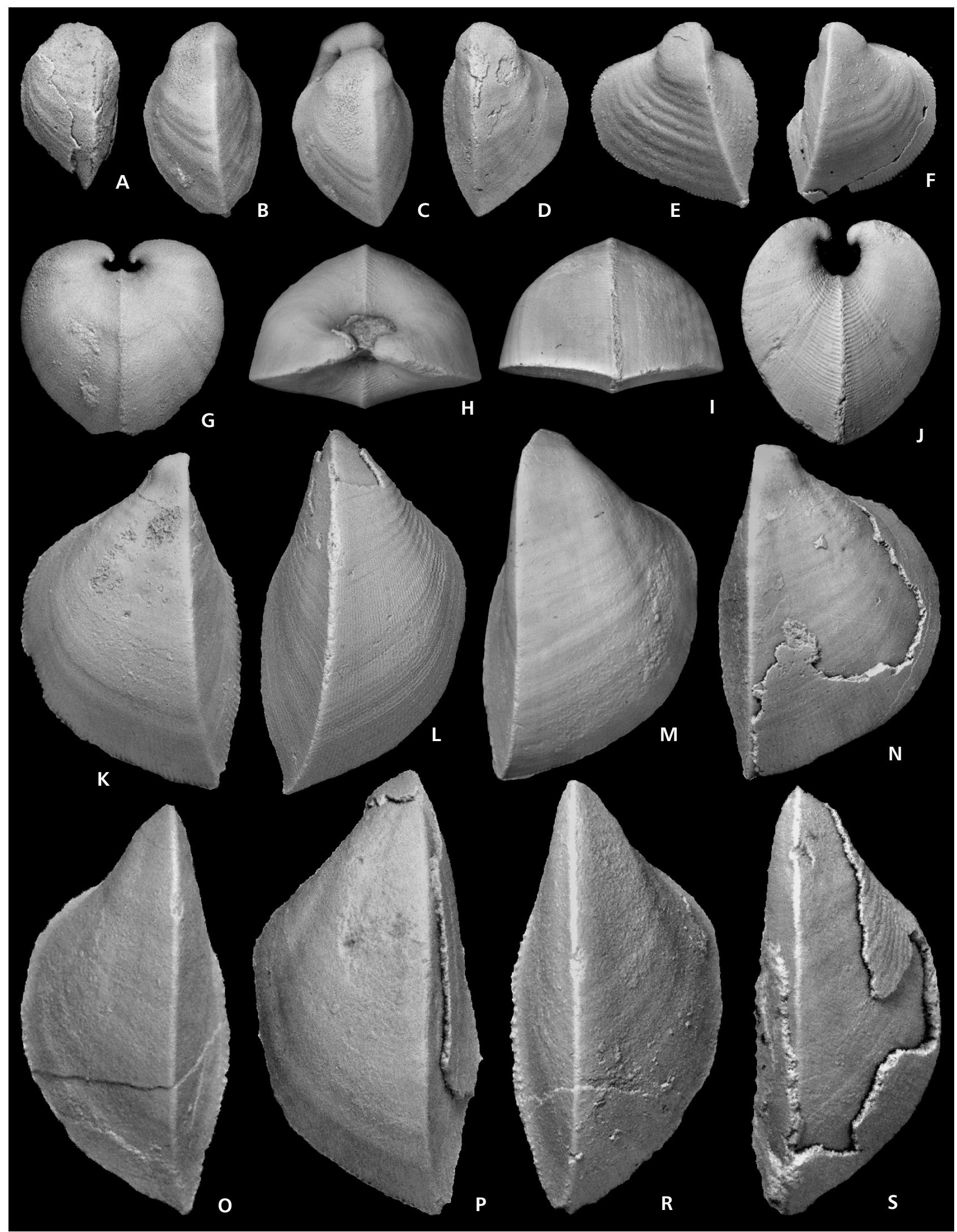


1993 Spanila cardiopsis Barrande, 1881; Kř̌iž in Kř́iž \& Serpagli, p. 332, pl. 8, figs 33, 35-38.

Lectotype (designated herein). - Shell with conjoined valves figured by Barrande (1881) on pl. 212, as figs II/1-5, NM L 21416.

Paralectotypes. - Shell with conjoined valves figured by Barrande (1881) on pl. 212, as figs II/6-8 (NM L 21 418), and left valve figured on pl. 212, as figs II/9-12 (NM L 21 417).

Type locality. - Bohemia, Prague Basin, Kozel Rocks near Beroun-Lištice.

Type horizon. - Ludlow, early Gorstian.

Material. - 18 articulated shells, 34 left and 30 right valves.

Diagnosis. - In adult shells the length/width relation (L/W) ranges from 1.1 to 0.5 (average 0.8 ), height/width relation (H/W) ranges from $0.8-1.3$ (average 1.1). Umbonal angle $44-89^{\circ}$ (average $66^{\circ}$ ). The shells are longer than in Kenzieana bellula from the late Wenlock (early Homerian), have more numerous radial ribs posteriorly of carina ( $>71$ in number) and thinner shell wall. Two blunt, possibly spoon like and quite long, slightly dorsally curved teeth are developed on the left valve. Between two corresponding sockets on the right valve is developed one long, spoon like tooth curved dorsally and leaning against the interspace between the teeth of the left valve.

Description. - Small, equivalve, inequilateral, prosocline, obliquely broadly obtriangular in outline, dorso-ventrally elongated, foreshortened, strongly inflated shells. In adult shells the high/length relation (H/L) ranges from 1.1 to 2.3 (average 1.5), length/width relation (L/W) ranges from 0.5 to 1.1 (average 0.8 ), height/width relation $(\mathrm{H} / \mathrm{W})$ ranges from $0.8-1.3$ (average 1.1). Umbonal angle $44-89^{\circ}$ (average $66^{\circ}$ ). Enantiomorphous (mostly equivalve but some specimens slightly inclined to the left or to the right). Pro- minent umbones in anterior terminal position, prosogyrate, with relatively large circular inflated opistogyrate prodissoconch preserved commonly on the beaks. Slighty inflated, subcircular or widely elliptical lanceolate frontal face very steep and wide, separated from the central part of the shell by carina curved anteriorly. Posterior sulcus indicates the presence of siphons. Outer surface with numerous rounded radial ribs ( $>71$ in number posteriorly of carina) and radial gutters in combination with numerous growth bands of approximately the same width. Both, the radial ribs and radial gutters broaden ventrally. In some specimens regular wide growth bands and furrows developed in umbonal part. Inner surface smooth, crenulations developed along the margin. Hinge margin short, straight. Two blunt, possibly spoon like and quite long, slightly dorsally curved teeth are developed on the left valve. Between two corresponding sockets on the right valve is developed one long, spoon like tooth curved dorsally and leaning against the interspace between the teeth of the left valve. Relatively high, triangular ligamental area with radial ribs. Shell thickness $0.14-0.28 \mathrm{~mm}$.

\section{Dimensions. -}

\begin{tabular}{|c|c|c|c|c|c|c|}
\hline & V & $\mathrm{L}$ & $\mathrm{H}$ & th/2 & $\mathrm{L} / \mathrm{W}$ & $\mathrm{H} / \mathrm{W}$ \\
\hline JK 10987 & A & 1.4 & 2.1 & 0.9 & 0.7 & 1.2 \\
\hline JK 8851 & $\mathrm{R}$ & 1.9 & 3.0 & 1.3 & 0.7 & 1.2 \\
\hline JK 8874 & $\mathrm{~L}$ & 1.9 & 2.5 & 1.2 & 0.8 & 1.0 \\
\hline JK 8837 & A & 2.0 & 2.8 & 1.4 & 0.7 & 1.0 \\
\hline JK 8852 & $\mathrm{R}$ & 2.0 & 4.6 & 2.2 & 0.5 & 1.0 \\
\hline JK 8877 & $\mathrm{R}$ & 2.3 & 4.4 & 1.8 & 0.6 & 1.2 \\
\hline JK 8827 & A & 2.7 & 4.2 & 2.2 & 0.6 & 1.0 \\
\hline JK 8854 & $\mathrm{R}$ & 2.9 & 3.8 & 1.6 & 0.9 & 1.2 \\
\hline JK 8840a & A & 3.2 & 6.1 & 2.9 & 0.6 & 1.1 \\
\hline JK 8855 & $\mathrm{R}$ & 3.8 & 4.8 & 1.8 & 1.1 & 1.3 \\
\hline JK 8878 & $\mathrm{R}$ & 3.9 & 5.1 & - & - & \\
\hline JK 8873 & $\mathrm{R}$ & 4.0 & 4.4 & 1.9 & 1.1 & 1.2 \\
\hline JK 8808 & $\mathrm{~L}$ & 4.2 & 5.4 & 2.1 & 1.0 & 1.3 \\
\hline JK 8875 & $\mathrm{R}$ & 4.3 & 4.8 & 2.0 & 1.1 & 1.2 \\
\hline JK 8883 & $\mathrm{~L}$ & 4.5 & 7.7 & 3.6 & 0.6 & 1.1 \\
\hline JK 8879 & $\mathrm{~L}$ & 4.6 & 5.8 & 2.2 & 1.1 & 1.3 \\
\hline JK 8807 & $\mathrm{~L}$ & 4.6 & 6.0 & 2.6 & 0.9 & 1.2 \\
\hline
\end{tabular}

Figure 3. A, B, D, E, J, N, O - Kenzieana cardiopsis (Barrande, 1881). • A, E - left valve with outer surface sculpture, NM L 21417, paralectotype; $\mathrm{A}-$ posterior view, $\times 5.1 ; \mathrm{E}-$ anterior view, $\times 4.5$. $\bullet \mathrm{B}$ - left valve with outer surface sculpture, NM L 22452, dorsal view, $\times 5.5$. $\bullet \mathrm{D}-$ shell with conjoined valves, JK 8827 , right valve up, latex mould, ventral view of hinge, $\times 19$. $\bullet \mathrm{J}-$ right valve, JK 8851 , posterior view, outer surface sculpture, $\times 15.3$. - $\mathrm{N}$ - left valve, JK 8887 , posterior view, detail of the outer and inner surface sculpture. $\times 5.5$. $\bullet \mathrm{O}$ - right valve, JK $11154 \mathrm{a}$, posterior view, detail of the outer surface sculpture; $\times 4.4$. $・ \mathrm{C}, \mathrm{L}, \mathrm{G}, \mathrm{H}, \mathrm{I}, \mathrm{K}, \mathrm{M}-$ Kenzieana bellula (Barrande, 1881). • C, L - JK 8832, left valve; C - posterior view, posterior adductor muscle scar (arrow); $\times 4.7 ; \mathrm{L}-$ posterior view, detail of outer and inner surface sculptures; $\times 6.8$. $\bullet \mathrm{G}-$ left valve, NM L 22424 , lectotype, postero-lateral view, outer and inner surface sculpture; $\times 6.1 . \bullet \mathrm{H}-$ right valve, JK 8833 , posterior view, inner surface sculpture and fragment of shell; $\times 6$. $\bullet \mathrm{I}$ - right valve, JK 8828 , anterior view, outer surface sculpture; $\times 9.9 . \bullet \mathrm{K}-$ left valve, JK 11236 , anterior view, inner surface sculpture; $\times 7$. $\bullet$ M - right valve, JK 8869 , posterior view, outer surface sculpture; $\times$ 8.9. • A, E - Kozel Rocks near Beroun-Lištice, lower Ludlow. • B - Praha-Lochkov, Ludlow. - C, D, J, N - Na Břekvici locality near Praha-Butovice, lower Ludlow, Neodiversograptus nilssoni Biozone. • G, H, L - Kační Quarry near

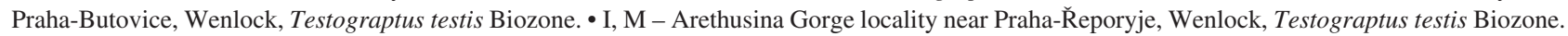
- K, O - Vyskočilka locality near Praha-Malá Chuchle, Wenlock, Testograptus testis Biozone. 


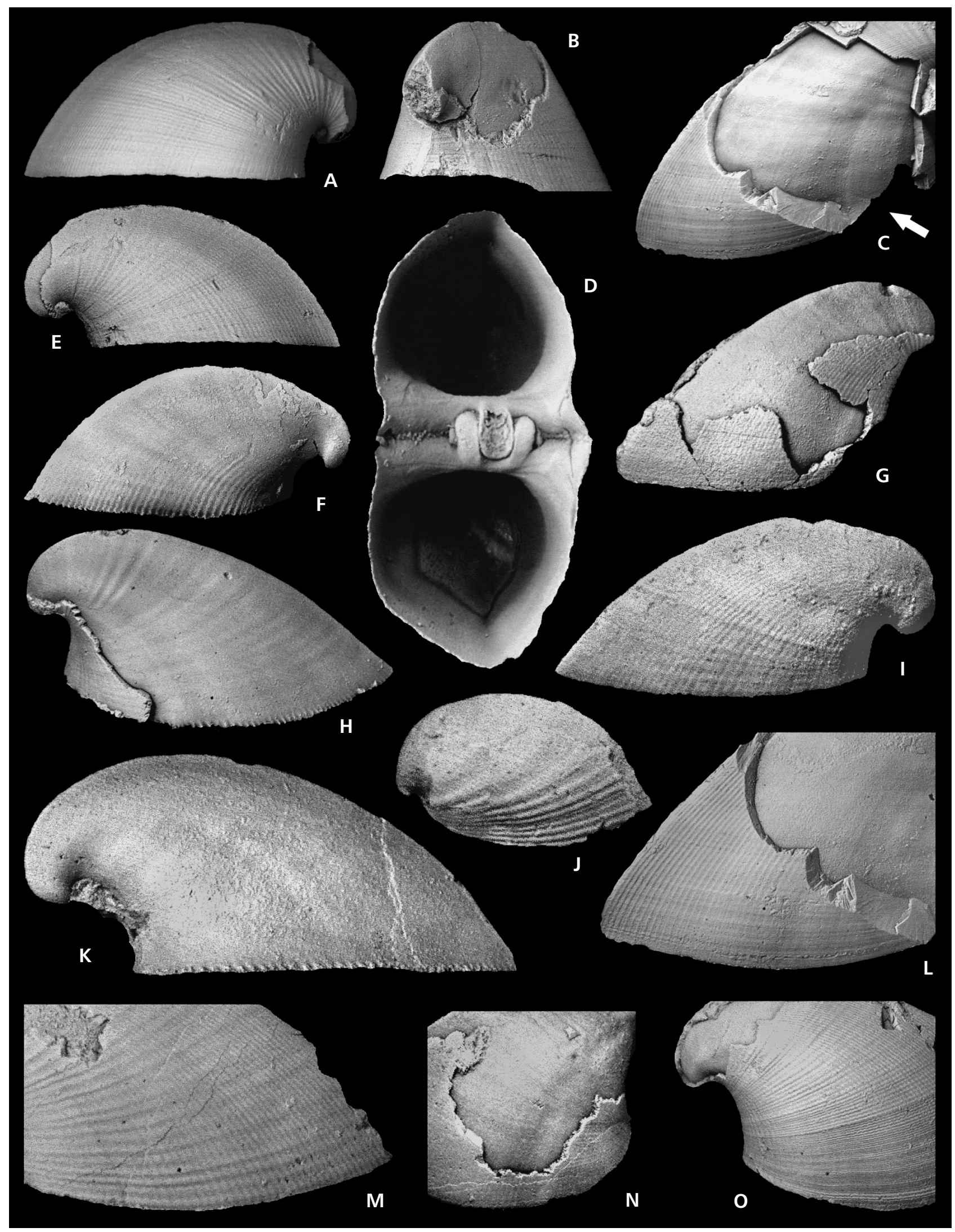




$\begin{array}{llrrrrr}\text { JK 8818 } & \text { R } & 4.8 & 7.7 & 3.4 & 0.7 & 1.1 \\ \text { JK 8821 } & \text { R } & 5.0 & 6.0 & 2.5 & 1.0 & 1.0 \\ \text { JK 8876 } & \text { L } & 5.0 & 6.6 & 2.9 & 0.9 & 0.9 \\ \text { JK 8849 } & \text { L } & 5.3 & 7.0 & 3.3 & 0.8 & 0.8 \\ \text { NM L 21418 L } & 5.6 & 7.3 & 3.3 & 0.8 & 1.1 \\ \text { NM L 21418 R } & 5.6 & 7.3 & 3.7 & 0.8 & 1.1 \\ \text { JK 11238 } & \text { A } & 5.6 & 10.4 & 4.7 & 0.6 & 1.1 \\ \text { JK 8850 } & \text { L } & 5.8 & 7.3 & 3.1 & 0.9 & 1.2 \\ \text { JK 8882 } & \text { L } & 5.8 & 8.8 & 3.7 & 0.8 & 1.2 \\ \text { JK 8880 } & \text { R } & 6.0 & 9.6 & 3.9 & 0.8 & 1.2 \\ \text { JK 8887 } & \text { L } & 7.1 & 11.0 & 4.8 & 0.7 & 1.1 \\ \text { NM L 21416 R } & 7.3 & 12.0 & 5.3 & 0.7 & 1.1 \\ \text { NM L 21416 L } & 7.3 & 12.0 & 5.1 & 0.7 & 1.1 \\ \text { NM L 21417 L } & 7.3 & 12.0 & 6.2 & 0.6 & 1.0 \\ \text { NM L 22452 L } & 7.4 & 13.0 & 5.8 & 0.6 & 1.1 \\ \text { JK 8848 } & \text { R } & 7.5 & 11.4 & 4.8 & 0.8 & 1.2 \\ \text { JK 8881 } & \text { R } & 7.9 & 12.8 & 5.9 & 0.7 & 1.1\end{array}$

Remarks. - Kenzieana cardiopsis, known already from the early Homerian (Cyrtograptus lundgreni Biozone) of Gotland represents long ranging form of Kenzieana (up to the Přídolí). Kenzieana bellula (Barrande, 1881) from the early Homerian (Testograptus testis Biozone) differs from Kenzieana cardiopsis (Barrande, 1881) mainly in the higher shells (average $\mathrm{H} / \mathrm{L}$ relation is 1.9 ) and smaller umbonal angle $36-62^{\circ}$ (average $43^{\circ}$ ).

Mode of life. - Kenzieana cardiopsis was most probably a very shallow and slow burrower resting or reclining in the sediment on its anterior, widely elliptical to subcircular and relatively flat frontal face with a few byssal threads attached to loose detrital sediment. It is known from the Prague Basin Cardiola gibbosa Community, Praha-Butovice, Neodiversograptus nilssoni Biozone, early Gorstian (Kř́̌ž 1999a), Cardiola donigala-Slava cubicula Community, Loděnice-Sedlec, and Cromus Hillslope near Reporyje, late Saetograptus chimaera Biozone, late Gorstian (Kř̌̌z 1999b), and from Sardinia Cardiola agna figusi Community, Wenlock-Ludlow boundary, Xea S'Antonio (Křǐž in Kř́ǐ \& Serpagli 1993).

Occurrence. - Bohemia, Prague Basin, Praha-Butovice, Praha-Braník, Praha-Velká Chuchle, Beroun-Lištice (early Gorstian, Neodiversograptus nilssoni Biozone), PrahaŘeporyje, Cromus Hillslope near Mušlovka Quarry, Loděnice-Bubovice (latest Gorstian, Saetograptus chimaera Biozone), Koledník near Beroun and Praha-Lochkov (early Ludfordian, Saetograptus linearis Biozone), Radotín Valley near U topolů Section (early Př́ídolí, Monograptus ultimus Biozone), Praha-Řeporyje, Lobolite Hillslope (late Přídolí, Monograptus transgrediens Biozone). Gotland (late Wenlock, Slite Beds, unit g, Cyrtograptus lundgreni Biozone), Italy, Sardinia (early Ludlow, early Gorstian).

\section{Kenzieana bellula (Barrande, 1881)}

Figures 2O-S, 3C, L, G, H, I, K, M

1881 Tetinka bellula Barr.; Barrande, pl. 244, figs II/5-8.

1881 Hemicardium debile Barr.; Barrande, pl. 183, figs V/1-8.

1989 Kenzieana angusta sp. n.; Liljedahl, pp. 234-236, figs 3 B, 6 A-F, 7, 8 D, 9 B.

Lectotype (designated herein). - Left valve figured by Barrande (1881) on pl. 244, as figs II/5-8, NM L 22424.

Type locality. - Bohemia, Prague Basin, Praha-Butovice.

Type horizon. - Wenlock, early Homerian, Testograptus testis Biozone.

Material. - Two shells with conjoined valves, 25 left and 24 right valves.

Diagnosis. - In adult shells the height/length relation (H/L) ranging from 1.4 to 2.2 (average 1.9), length/width relation (L/W) ranging from 0.5 to 0.7 (average 0.6 ), height/width relation $(\mathrm{H} / \mathrm{W}$ ) ranging from $0.9-1.5$ (average 1.2). Umbonal angle is $36-62^{\circ}$ (average $43^{\circ}$ ). The shells are distinctly higher than in Kenzieana cardiopsis from the early Ludlow and have less numerous radial ribs posteriorly of carina ( $>63$ in number). Hinge unknown. Posterior adductor muscle scar developed close to ventral margin, and above the posterior radial sulcus.

Description. - Small, equivalve, inequilateral, prosocline, obliquelly obtriangular in outline, dorso-ventrally elongated, strongly inflated shells. In adult shells the height/length relation $(\mathrm{H} / \mathrm{L}$ ) ranging from 1.4 to 2.2 (average 1.9), length/width relation (L/W) ranging from 0.5 to 0.7 (average 0.6 ), height/width relation $(\mathrm{H} / \mathrm{W}$ ) ranging from $0.9-1.4$ (average 1.2). Umbonal angle $36-62^{\circ}$ (average $43^{\circ}$ ). The shells of Kenzieana bellula are distinctly higher than in Kenzieana cardiopsis from the early Ludlow. Enantiomorphous (mostly equivalve but some specimens are slightly inclined to the left or to the right). Prominent umbones are in anterior terminal position, prosogyrate, with relatively large circular inflated opistogyrate prodissoconch on the beaks. Slightly inflated, subcircular or widely elliptical lanceolate frontal face very steep and wide, separated from the central part of the shell by carina curved anteriorly. Posterior sulcus indicates the presence of siphons. Outer surface with numerous rounded radial ribs (> 63 in number posteriorly of carina) and radial gutters in combination with numerous growth bands of approximately the same width. Both, the radial ribs and radial gutters broaden ventrally. Inner surface smooth, crenulations developed along the margin. Hinge 
margin short, straight. Hinge unknown. Posterior adductor muscle scar developed close to ventral margin, and above the posterior radial sulcus. Shell thickness $0.18-0.4 \mathrm{~mm}$.

\section{Dimensions. -}

\begin{tabular}{|c|c|c|c|c|c|c|}
\hline & V & $\mathrm{L}$ & \multicolumn{2}{|c|}{$\mathrm{H}$ width$/ 2$} & $\mathrm{~L} / \mathrm{W}$ & $\mathrm{H} / \mathrm{W}$ \\
\hline JK 8828 & $\mathrm{R}$ & 4.0 & 7.0 & 2.9 & 0.7 & 1.3 \\
\hline JK 8869 & $\mathrm{R}$ & 4.8 & 9.2 & 3.9 & 0.6 & 1.2 \\
\hline JK 8860 & $\mathrm{~L}$ & 4.9 & 11.0 & 4.6 & 0.5 & \\
\hline JK 8825 & $\mathrm{~L}$ & 5.1 & 11.0 & 4.3 & 0.6 & \\
\hline NM L 22424 & $\mathrm{~L}$ & 5.1 & 11.7 & 4.2 & 0.6 & \\
\hline JK 11146 & $\mathrm{~L}$ & 5.2 & 9.4 & 4.1 & 0.6 & \\
\hline JK 8830 & $\mathrm{~L}$ & 5.3 & 10.6 & 4.8 & 0.6 & \\
\hline JK 8814 & $\mathrm{R}$ & 5.6 & 9.5 & 4.1 & 0.7 & \\
\hline JK 8813 & $\mathrm{~L}$ & 5.7 & 10.9 & 5.1 & 0.6 & \\
\hline JK 8861 & $\mathrm{~L}$ & 5.8 & 10.2 & 4.5 & 0.6 & \\
\hline JK 8838 & $\mathrm{R}$ & 5.8 & 12.1 & 4.8 & 0.6 & \\
\hline JK 8826 & $\mathrm{R}$ & 5.9 & 10.3 & 4.1 & 0.7 & \\
\hline JK 8872 & $\mathrm{R}$ & 5.9 & 11.2 & 4.9 & 0.6 & \\
\hline JK 8829 & $\mathrm{~L}$ & 6.0 & 11.1 & 4.9 & 0.6 & \\
\hline JK 11236 & $\mathrm{~L}$ & 6.2 & 12.8 & 5.3 & 0.6 & \\
\hline JK 8812 & $\mathrm{R}$ & 6.5 & 12.1 & 5.4 & 0.6 & \\
\hline JK 8845 & $\mathrm{R}$ & 6.5 & 12.4 & 5.1 & 0.6 & \\
\hline JK 8816 & $\mathrm{~L}$ & 7.3 & 16.4 & 6.1 & 0.6 & \\
\hline JK 11152 & $\mathrm{R}$ & 7.8 & 13.5 & 7.3 & 0.53 & \\
\hline
\end{tabular}

Mode of life. - Kenzieana bellula was most probably a very shallow and slow burrower, resting or reclining in the sediment on its anterior, widely elliptical and flatter frontal face with a few byssal threads attached to loose detrital sediment. It is known from the Prague Basin Cardiola agna Community, Arethusina Gorge near Praha- ̌̌eporyje, late Wenlock, early Homerian, Testograptus testis Biozone (Kř́ž 1999a).

Occurrence. - Bohemia, Prague Basin, Praha-Řeporyje, Arethusina Gorge, Praha-Malá Chuchle, Vyskočilka Section above the road, and in the Malá Chuchle Valley, Praha-Pankrác, Praha-Motol, Beroun-Lištice, Kozel, Praha-Butovice, Tachlovice (late Wenlock, early Homerian, Testograptus testis Biozone). Gotland (late Wenlock, Slite Beds, unit g, Cyrtograptus lundgreni Biozone).

\section{Conclusions}

1. Kenzieana Liljedahl, 1989 from the late Wenlock (early Homerian) represents the oldest known genus of the family Spanilidae Kř́̌̌̌, 2007, most probably derived from the late Llandovery Stolidotidae Starobogatov, 1977.

2. Kenzieana is very long ranging Silurian genus (late Wenlock to late Přídolí) and was most probably the ances- tor of the Gorstian Algerina Křiž, 2008, and the Ludfordian Spanila Barrande, 1881.

3. Distinctly inflated, foreshortened shells with almost flat and circular frontal face represent in Kenzieana adaptive convergence with the Silurian Slavinka plicata (Barrande, 1881), and Recent Corculum Röding, 1798, Fragum Röding, 1798.

4. Kenzieana was very shallow and slow burrower resting or reclining in the sediment on its anterior, almost subcircular or widely elliptical and flat frontal face with a few byssal threads attached to loose detritus.

\section{Acknowledgments}

I am indebted to John C.W. Cope, National Museum of Wales, Cardiff, for valuable suggestions, constructive comments and linguistic improvement and to Štěpán Manda, Czech Geological Survey, Prague, for the technical help with manuscript, for the digitalization of the schematic picture and for good suggestion. Vojtěch Turek and Martin Valent, National Museum, Prague kindly provided access to the collections. The research was funded by GA ČR (Czech Science Foundation) project 205/09/0703.

\section{References}

BARRANDE, J. 1881. Systême silurien du centre de la Bohême. Classe des Mollusques, ordre des Acéphalés. 6. 342 pp., Prague \& Paris.

CONRATH, P. 1887. Über einige silurische Pelecypoden. Sitzungsberichte der Kaiserlichen Akademie der Wissenschaften, Mathematisch-Naturwissenschaftliche Klasse 96, 40-51.

KŘíž, J. 1969. Genus Butovicella Kříž, 1965 in the Silurian of Bohemia (Bivalvia). Sborník geologických věd, Palaeontologie 10, 105-139.

KŘíž, J. 1985. Silurian Slavidae (Bivalvia). Sborník geologických věd, Palaeontologie 27, 47-111.

KŘíž, J. 1999a. Bivalvia dominated communities of Bohemian type from the Silurian and Lower Devonian carbonate facies, 229-252. In BOUCOT, A.J. \& LAWSON, J.D. (eds) Final report, project Ecostratigraphy. Paleocommunities: A case study from the Silurian and Lower Devonian. 895 pp.Cambridge University Press, Cambridge.

KŘíž, J. 1999b. Cephalopod limestone biofacies on the northern slopes of the Silurian volcanic archipelago in the Prague Basin containing re-described benthic Cardiola donigala-Slava cubicula Community (Bivalvia, Barrandian, Bohemia). Journal of the Czech Geological Society 44(1-2), 159-165.

KŘíž, J. 2007. Origin, evolution and classification of the new superorder Nepiomorphia (Mollusca, Bivalvia, Lower Paleozoic). Palaeontology 50(6), 1341-1365. DOI 10.1111/j.1475-4983.2007.00720.x 
Ǩ̌íž, J. 2008. Algerina gen. nov. (Bivalvia, Nepiomorphia) from the Silurian of the North Gondwana margin (Algeria), peri-Gondwanan Europe (France, Italy), Perunica (Prague Basin, Bohemia) and the Siberian Plate (Tajmyr Basin, Russia). Bulletin of Geosciences 83(1), 79-84. DOI 10.3140/bull.geosci.2008.01.079

KŘíž, J. \& SERPAGLI, E. 1993. Upper Silurian and lowermost Devonian Bivalvia of Bohemian type from south-western Sardinia. Bolletino della Società Paleontologica Italica 32, 289-347.

LAMARCK, J.B. DE 1799. Prodrome d'une nouvelle classification des coquilles, comprenant une rédaction appropriée des caractères géneriques, et l'établissement d'un grand nombre de genres nouveaux. Mémories de la Société d' Histoire Naturelle Paris 1, 63-91.

LILJEDAHL, L. 1989. Two micromorphic bivalves from the Silurian of Gotland. Paläontologische Zeitschrift 63, 229-240.
LINNÉ, C. 1758. Systema naturae per regna tria naturae, secundum classes, ordines, genera, species, cum characteribus, differentiis, synonymis, locis. Edit Decima, reformata. 824 pp. Holmiae.

RÖDING, J. 1798. Museum Boltenianum, sive, Catalogus cimeliorum e tribus regnis naturae quae olim collegerat Joa. Fried. Bolten: pars secunda continens conchylia sive testacea univalvia, bivalvia \& multivalvia. viii +119 pp. Typis Johan Christi Trapii, Hamburg.

STANLEY, S.M. 1970. Relation of shell form to life habits in the Bivalvia (Mollusca). Memoir of the Geological Society of America 125, 1-296.

StAROBOGATOV, Y.I. 1977. Sistematicheskoje polozhenije konokardiid i sistema paleozoiskikh Septibranchia (Bivalvia). Byulleten Moskovskogo Obshchestva Ispytatelei Prirody, Otdel geologicheskii 52(4),125-139. 